\title{
Land-Use Change Enhanced SOC Mineralization but Did Not Significantly Affect Its Storage in the Surface Layer
}

\author{
Haikuo Zhang ${ }^{1,2}$, Xuli Zheng ${ }^{3}$, Yanjiang Cai ${ }^{1,2, *(\mathbb{D})}$ and Scott X. Chang ${ }^{1,4}$ (D) \\ 1 State Key Laboratory of Subtropical Silviculture, Zhejiang A\&F University, Hangzhou 311300, China; \\ hkzhang@zafu.edu.cn (H.Z.); scott.chang@ualberta.ca (S.X.C.) \\ 2 College of Environmental and Resource Sciences, Zhejiang A\&F University, Hangzhou 311300, China \\ 3 Anji County Lingfeng Temple Forest Farm, Huzhou 313302, China; zx10326@163.com \\ 4 Department of Renewable Resources, University of Alberta, 442 Earth Sciences Building, \\ Edmonton, AB T6G 2E3, Canada \\ * Correspondence: yjcai@zafu.edu.cn; Tel.: +86-6370-5212
}

check for

updates

Citation: Zhang, H.; Zheng, X.; Cai, Y.; Chang, S.X. Land-Use Change Enhanced SOC Mineralization but Did Not Significantly Affect Its Storage in the Surface Layer. Int. J. Environ. Res. Public Health 2022, 19, 3020. https://doi.org/10.3390/ ijerph19053020

Academic Editors: Xiaobo Qin and Jianling Fan

Received: 2 December 2021

Accepted: 28 February 2022

Published: 4 March 2022

Publisher's Note: MDPI stays neutral with regard to jurisdictional claims in published maps and institutional affiliations.

Copyright: (c) 2022 by the authors. Licensee MDPI, Basel, Switzerland. This article is an open access article distributed under the terms and conditions of the Creative Commons Attribution (CC BY) license (https:// creativecommons.org/licenses/by/ $4.0 /)$.

\begin{abstract}
To achieve carbon $(\mathrm{C})$ neutrality and mitigate climate change, it is crucial to understand how converting natural forests to agricultural plantations influences soil organic $C$ (SOC) mineralization. In this study, we investigated the impact of converting evergreen broadleaf forests (EBF) to extensively managed Moso bamboo (Phyllostachys edulis (Carriere) J. Houzeau) plantations (MBP) in subtropical China on SOC mineralization rate; the concentrations of labile SOC fractions such as dissolved organic C (DOC), microbial biomass $C(\mathrm{MBC})$, and readily oxidizable $C$ (ROC); the activities of $\mathrm{C}$-degrading enzymes (cellobiohydrolase and phenol oxidase); and the abundance of C-degrading enzyme-encoding genes $(c b h \mathrm{I}$ and $l c c)$. Three paired soil samples were taken from the surface layer $(0-20 \mathrm{~cm})$ of adjacent EBF-MBP sites in Anji County, Zhejiang province. Results showed that converting EBF to MBP significantly increased the SOC mineralization rate as well as soil $\mathrm{pH}, \mathrm{MBC}$, cellobiohydrolase, and phenol oxidase activities, and $c b h$ I gene abundance, but did not change other soil properties described above. In addition, structural equation modelling (SEM) showed that the conversion increased SOC mineralization rate through increasing soil $\mathrm{pH}, c b h \mathrm{I}$ gene abundance, $\mathrm{MBC}$, and cellobiohydrolase and phenol oxidase activities. Our novel finding that converting EBF to extensively managed MBP enhanced SOC mineralization via increasing the activities of $\mathrm{C}$-degrading enzymes suggests that $\mathrm{C}$-degrading enzymes were a key factor regulating SOC mineralization in the extensively managed subtropical bamboo plantations.
\end{abstract}

Keywords: carbon-degrading enzyme activity; forest conversion; soil organic carbon mineralization

\section{Introduction}

Globally, approximately $39 \%$ of soil organic carbon (SOC) is stored in forest ecosystems [1]. In forest ecosystems, SOC accounts for about $67 \%$ of the total carbon (C) pool [2] Therefore, the mineralization of forest SOC plays a vital role in global $\mathrm{C}$ neutrality and atmospheric carbon dioxide $\left(\mathrm{CO}_{2}\right)$ concentration $[3,4]$. One of the critical factors affecting forest SOC sequestration is the changes in land use. Conversion of natural forests to more intensively managed forests or agricultural lands has frequently been done in the past several decades across the world to obtain more economic benefits and meet the demand for food and fiber due to increasing population $[5,6]$. For example, $83 \%$ of new agricultural lands in the tropics was converted from natural forests between 1980 and 1990 [7]. Generally, forest conversion and field management practices that follow the conversion change above- and below-ground litter input to soils [8,9], which will inevitably affect the dynamics of SOC $[3,10]$. The conversion of natural forests to agroforestry plantations $[3,11]$ and pine plantations [12] has been found to increase $\mathrm{CO}_{2}$ emissions. However, some studies of converting natural forests to forest plantations found negative or no effect on soil $\mathrm{CO}_{2}$ 
emissions [13-15]. Therefore, the mechanisms mediating soil $\mathrm{CO}_{2}$ emissions under forest conversion need to be further studied.

The mineralization of SOC is one of the main sources of soil $\mathrm{CO}_{2}$ emissions $[16,17]$; the rate of SOC mineralization thus reflects the dynamics of SOC $[18,19]$. In general, environmental factors such as humidity and temperature are thought to influence the SOC mineralization $[1,4]$. Additionally, the labile SOC fractions such as readily oxidizable $C$ (ROC) and dissolved organic $C$ (DOC) generally serve as the main $C$ sources for microbial respiration that controls SOC mineralization $[20,21]$. Due to its high sensitivity to environmental changes, labile SOC fractions are generally considered a potential predictor of SOC mineralization after forest conversion [22-25]. For example, Lin et al. [13] found that converting natural evergreen broadleaf forests to intensively managed Moso bamboo (Phyllostachys edulis (Carriere) J. Houzeau) plantations decreased SOC mineralization rate, which was significantly related to soil ROC and DOC. Lyu et al. [10] also observed that cumulative SOC mineralization in the topsoil was significantly decreased by forest conversion due to the depletion of soil DOC and microbial biomass carbon (MBC). In addition to the availability of labile SOC, extracellular enzymes secreted by soil microbes play an essential role in SOC mineralization, as they catalyze the breakdown of soil organic matter (SOM) until the products can be assimilated by microbes [26,27]. Cellulose and lignin are two of the most abundant organic compounds in SOM and the main energy source of microbe-mediated SOC mineralization [28-30]. For example, cellobiohydrolase can hydrolyze cellulose, and phenol oxidase can oxidize lignin; these two C-degrading enzymes are crucial for SOC mineralization [30-32]. Soil C-degrading enzyme activities can be also affected by forest conversion. For instance, Lin et al. [13] observed that forest conversion significantly decreased soil cellobiohydrolase activity. Zhang et al. [33] found that converting forests into croplands significantly increased the activity of soil phenol oxidase in the subtropics. Moreover, soil enzyme activities were closely related to associated enzyme-encoding genes [34,35]. Soil cellobiohydrolase activity was found to be positively correlated with the abundance of fungal $c b h$ I gene in a subtropic region [36]. In spite of this, few studies about forest conversion examined both soil C-degrading enzyme activities and the associated enzyme-encoding gene abundances. In addition, there is also a lack of studies on how soil C-degrading enzymes and associated enzyme-encoding genes mediate SOC mineralization in the context of forest conversion.

Moso bamboo plantations are one of the most important forest resources in subtropical China. Most Moso bamboo plantations were converted from natural forests due to high economic benefits provided by the Moso bamboo plantations in the past several decades $[37,38]$. Previous studies have reported the effects of converting natural forests to intensively managed Moso bamboo plantations on SOC dynamics [13,37,39,40]. However, extensively managed Moso bamboo plantations converted from natural forests are also common in subtropical China [41]. Unlike intensively managed Moso bamboo plantations, extensively managed Moso bamboo plantations are generally not managed with deep ploughing, fertilizer application, or understory vegetation removal [41]. The characteristics of SOC mineralization after forest conversion to extensively managed Moso bamboo plantations may therefore be different with those in the intensively managed Moso bamboo plantations. It is essential to explore the characteristics of SOC mineralization after converting natural forests to extensively managed Moso bamboo plantations.

The present study aimed to investigate the effect of converting natural forests to extensively managed Moso bamboo plantations on SOC mineralization and the relationship between SOC mineralization and labile SOC fractions (DOC, ROC, and MBC), C-degrading enzyme (cellobiohydrolase, phenol oxidase) activities, and the abundance of associated enzyme-encoding genes ( $c b h \mathrm{I}$ and $l c c)$. We hypothesize that: (1) converting natural forests to extensively managed Moso bamboo plantations will not decrease the concentrations of total SOC and labile SOC fractions, as the aboveground vegetation was preserved in extensively managed MBP; (2) such forest conversion mediates SOC mineralization rates by regulating both the $\mathrm{C}$-degrading enzyme activities and labile $\mathrm{SOC}$ fractions because 
SOC mineralization and the C-degrading enzyme activities and the labile SOC fractions are closely linked; and (3) the change in the activities of the C-degrading enzymes influenced by such forest conversion is linked to the abundance of associated enzyme-encoding genes.

\section{Materials and Methods}

\subsection{Study Site and Soil Sampling}

The study was conducted in a typical hilly region in Anji County $\left(30^{\circ} 41^{\prime} \mathrm{N}, 119^{\circ} 46^{\prime} \mathrm{E}\right)$, in the northern part of Zhejiang Province, China. The study area has a north subtropical monsoon climate, with a mean annual temperature of $17.0^{\circ} \mathrm{C}$ and a mean annual precipitation of $1706.2 \mathrm{~mm}$. The soil is classified as a Ferralsol [42]. The native vegetation in the study area is the natural evergreen broadleaf forest (EBF). The EBF has existed for at least 100 years, and the tree species were dominated by Cyclobalanopsis glauca, Castanopsis sclerophylla, and Schima superba Gardn. Local farmers have been converting part of the EBF into the Moso bamboo plantation (MBP) since 2000 with the increasing demand for bamboo resources. The MBP was extensively managed after the conversion, including harvesting of bamboo stems and shoots (without deep ploughing, fertilizer application, and understory vegetation removal). Three pairs of sampling plots (two different land-use types in each pair, i.e., natural evergreen broadleaf forest and Moso bamboo plantation) were selected after a field survey in June 2019. All sampling plots had the same land-use change history and the similar geographical characteristic (altitude, slope, aspect, soil parent materials, and so on). Each sampling plot was approximately $20 \times 20 \mathrm{~m}$.

We collected surface $(0-20 \mathrm{~cm})$ soil samples two times in the growing season (July and October 2019). Briefly, five soil cores were obtained from the center and four corners of each sampling plot, mixed to form a composite sample per plot, and brought back to the laboratory. In the laboratory, soil samples were passed through a $2 \mathrm{~mm}$ sieve to remove visible roots and divided into three parts, i.e., air-dried at room temperature, stored at $4{ }^{\circ} \mathrm{C}$, and stored at $-80^{\circ} \mathrm{C}$ for subsequent analysis.

\subsection{Determination of Soil Physicochemical Properties and Labile SOC Fractions}

Soil bulk density (BD) was measured by the bulk density ring method in July 2019. Soil texture was characterized using a laser size detector (Malvern Panalytical Mastersizer 3000E, UK). Soil pH was determined in a suspension with a 1:2.5 (w:v) soil to distilled water ratio using a pH meter (Mettler Toledo Seven Compact S210, Zurich, Switzerland). Soil moisture content was determined by oven-drying soil samples at $105^{\circ} \mathrm{C}$ to a constant mass. The concentration of SOC was determined by the oxidation method using $\mathrm{K}_{2} \mathrm{Cr}_{2} \mathrm{O}_{7^{-}}$ $\mathrm{H}_{2} \mathrm{SO}_{4}$ [43]. The total $\mathrm{N}$ concentration was determined by an auto-analyzer (Hanon K9860, Shandong, China) after micro-Kjeldahl digestion [44]. The following formula was used to calculate the SOC storage: SOC storage $\left(\mathrm{Mg} \mathrm{ha}^{-1}\right)=\mathrm{SOC}\left(\mathrm{Kg} \mathrm{Mg}^{-1}\right) \times \mathrm{BD}\left(\mathrm{Mg} \mathrm{m}^{-3}\right) \times$ depth $(\mathrm{m}) \times 10$.

To determine the concentration of DOC, $5 \mathrm{~g}$ (on an oven-dry basis) fresh soil was extracted in $25 \mathrm{~mL}$ deionized water, and the slurry was shaken at $250 \mathrm{rpm}$ for $30 \mathrm{~min}$ on a shaker. The sample was then centrifuged at $5000 \times g$ for $20 \mathrm{~min}$ and filtered through a $0.45-\mu \mathrm{m}$ membrane filter (JINTENG $\Phi 25$, Tianjin, China). The C concentration in the extracts were determined using a TOC analyzer (Multi N/C3100, Analytik Jena AG, Jena, Germany). The concentration of $\mathrm{MBC}$ was analyzed using the chloroform fumigationextraction method $[45,46]$. Briefly, two $5 \mathrm{~g}$ (on an oven-dry basis) fresh soil samples (one fumigated and one non-fumigated) were extracted in $25 \mathrm{~mL} 0.5 \mathrm{M} \mathrm{K}_{2} \mathrm{SO}_{4}$. The extracts were filtered through $0.45-\mu \mathrm{m}$ membrane filters and then the soluble $\mathrm{C}$ concentration was measured by the TOC analyzer. The concentration of $\mathrm{MBC}$ was calculated as the difference in $C$ concentration in the extracts between fumigated and non-fumigated soils, and based on an extraction efficiency factor of 0.45 [47]. The ROC concentration was measured by the $\mathrm{KMnO}_{4}$ oxidation method [48]. Briefly, $2 \mathrm{~g}$ air-dried soil sample was extracted in $25 \mathrm{~mL}$ $0.333 \mathrm{M} \mathrm{K}_{2} \mathrm{MnO}_{4}$ solution and shaken at $200 \mathrm{rpm}$ for $1 \mathrm{~h}$, then centrifuged at $5000 \times g$ for $5 \mathrm{~min}$. The supernatant was passed through qualitative filter papers (Whatman ${ }^{\circledR}$ No. 42 , 
Cytiva, Buckinghamshire, UK), and then the absorbance was determined at $565 \mathrm{~nm}$ using a UV spectrophotometer (UV-2600, Shimadzu, Kyoto, Japan).

\subsection{Determination of Soil C-Degrading Enzyme Activities}

We analyzed the activities of cellobiohydrolase and phenol oxidase using fluorometric techniques with 96-well microplates [49,50]. Briefly, $1.5 \mathrm{~g}$ (on an oven-dry basis) fresh soil was weighed and suspended in $125 \mathrm{~mL}$ sodium acetate buffer $(50 \mathrm{mM}, \mathrm{pH}=5.0)$. For cellobiohydrolase, the three rows of the sample group in the 96-well microplate included $200 \mu \mathrm{L}$ soil slurries combined with a $50 \mu \mathrm{L}$ cellobiohydrolase substrate $(200 \mu \mathrm{M}), 200 \mu \mathrm{L}$ soil slurries combined with $50 \mu \mathrm{L}$ sodium acetate buffer, and $200 \mu \mathrm{L}$ soil slurries combined with $50 \mu \mathrm{L}$ standard substrate of 4-methylumbelliferone; the three rows of the control group included $200 \mu \mathrm{L}$ sodium acetate buffer combined with $50 \mu \mathrm{L}$ cellobiohydrolase substrate, $250 \mu \mathrm{L}$ sodium acetate buffer, and $200 \mu \mathrm{L}$ sodium acetate buffer combined with $50 \mu \mathrm{L}$ 4-methylumbelliferone standard substrate. For phenol oxidase, the two rows of the sample group included $200 \mu \mathrm{L}$ soil slurries combined with $50 \mu \mathrm{L}$ L-DOPA $(25 \mathrm{mM})$ and $200 \mu \mathrm{L}$ soil slurries combined with $50 \mu \mathrm{L}$ sodium acetate buffer; the two rows of the control group included $200 \mu \mathrm{L}$ sodium acetate buffer combined with $50 \mu \mathrm{L}$ L-DOPA, and $250 \mu \mathrm{L}$ sodium acetate buffer. The microplate of cellobiohydrolase was incubated in the dark at $25{ }^{\circ} \mathrm{C}$ for $3 \mathrm{~h}$, and phenol oxidase was incubated in the dark at $25^{\circ} \mathrm{C}$ for $24 \mathrm{~h}$. The fluorescence value of cellobiohydrolase with $365 \mathrm{~nm}$ excitation and $450 \mathrm{~nm}$ emission, and the absorbance value of phenol oxidase with $450 \mathrm{~nm}$ absorbance were determined using a microplate reader (Biotek ${ }^{\circledR}$ Synergy H1, Winooski, VT, USA). The activities of cellobiohydrolase and phenol oxidase were expressed as nmol g ${ }^{-1} \mathrm{~h}^{-1}$ and $\mu \mathrm{mol} \mathrm{g}^{-1} \mathrm{~h}^{-1}$, respectively.

\subsection{Soil DNA Extraction and Quantitative PCR}

The PowerSoil ${ }^{\circledR}$ Pro DNA Isolation Kit (MOBIO, Qiagen, Germany) was used for soil DNA extractions. The ABI QuantStudio 3 Real Time PCR System (ABI QuantStudio 3, Thermo Fisher Scientific, Germany) was used to quantify the abundance of fungal Cdegrading functional genes $c b h \mathrm{I}$ and $l c c$ in the soils. The amplification primers of fungal $c b h \mathrm{I}$ and $l c c$ are fungcbhIF (ACC AAY TGC TAY ACI RGY AA)/fungcbhIR (GCY TCC CAI ATR TCC ATC) [28] and fungCu1F (CAY TGG CAY GGN TTY TTY CA)/fungCu2R (RCT GTG GTA CCA GAA NGT NCC) [51], respectively. The reaction mixture system $(20 \mu \mathrm{L})$ contained $10 \mu \mathrm{L}$ SYBR ${ }^{\circledR}$ Premix EX TaqTM (Takara RR420a, Shiga, Japan), $0.2 \mu \mathrm{L}$ $(50 \mathrm{mM})$ forward primer, $0.2 \mu \mathrm{L}(50 \mathrm{mM})$ reverse primer, $1 \mu \mathrm{L}$ template DNA $(1-10 \mathrm{ng})$,

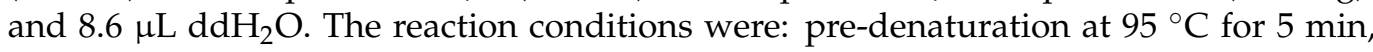
followed by 35 cycles of denaturation at $95^{\circ} \mathrm{C}$ for $30 \mathrm{~s}$, annealing at $56^{\circ} \mathrm{C}(l c c)$, or $57^{\circ} \mathrm{C}$ (cbhI) for $30 \mathrm{~s}$, extension at $72{ }^{\circ} \mathrm{C}$ for $30 \mathrm{~s}$; the final extension was $15 \mathrm{~min}$ at $72{ }^{\circ} \mathrm{C}$. The amplification efficiency of the genes was $89-105 \%$, with $\mathrm{R}^{2}$ values more than 0.993 . The target gene copy numbers were determined by a standard curve generated using purified template plasmid DNA.

\subsection{Determination of Soil Organic C Mineralization Rates}

A one-month aerobic incubation was conducted to determine the SOC mineralization rate. Briefly, $30 \mathrm{~g}$ (on an oven-dry basis) fresh soil of each sample was adjusted to $60 \%$ water holding capacity by adding deionized water and stored in a $250 \mathrm{~mL}$ flask at $25^{\circ} \mathrm{C}$ incubator for 33 days. The flasks were weighed every 2-3 days, and deionized water was added as needed to keep soil moisture content constant. Headspace gas samples were collected from flasks on days 1, 2, 3, 5, 7, 9, 11, 16, 21, 27, and 33. Before each gas sampling, the flasks were sealed tightly using rubber stoppers and liquid silicone rubber (NQ-704 adhesive sealant, Nanjing, China). A $20 \mathrm{~mL}$ volume of air was injected into the flask with a syringe and mixed with the gas in the headspace; a $20 \mathrm{~mL}$ gas sample was then withdrawn to ensure the internal and external pressure balance of the flasks. The $20 \mathrm{~mL}$ gas sample collected was injected into a $12 \mathrm{~mL}$ vacuum vial (LabCo Exetainer ${ }^{\circledR}$, High Wycombe, UK) and used as the background sample. The flasks were then placed into a $25^{\circ} \mathrm{C}$ incubator for 
$4 \mathrm{~h}$ and another $20 \mathrm{~mL}$ sample of headspace gas was collected from the flask and injected into a $12 \mathrm{~mL}$ vacuum vial. The $\mathrm{CO}_{2}$ concentrations from all gas samples were determined using a gas chromatograph (Agilent ${ }^{\circledR} 7890 \mathrm{~B}$, Santa Clara, CA, USA). The difference of the $\mathrm{CO}_{2}$ concentrations between the two sampling times was used to calculate the soil $\mathrm{CO}_{2}$ emission rate $\left(C_{R}\right)$ for the day. The cumulative total $\mathrm{CO}_{2}-\mathrm{C}$ emission $\left(\mathrm{mg} \mathrm{kg}^{-1}\right)$ during the 33-day incubation period was defined as the cumulative amount of SOC mineralization $\left(\mathrm{mg} \mathrm{kg}^{-1}\right)$. The following formula was used to calculate the cumulative amount of SOC mineralization $\left(\mathrm{C}_{\min }\right)$ :

$$
\begin{gathered}
\mathrm{C}_{\mathrm{R}}=\left[(28 / 22.41) \times \Delta \mathrm{C} \times \mathrm{V} \times 10^{-6} \times 237\right] /\left[\mathrm{M} \times \Delta \mathrm{t} \times 10^{-3} \times(237+\mathrm{T})\right] \\
\mathrm{C}_{\min }=\sum(i=1)^{\wedge} \mathrm{n}\left(\mathrm{C}_{\mathrm{R}(i)}+\mathrm{C}_{\mathrm{R}(i+1)}\right) / 2 \times\left(\mathrm{t}_{i+1}-\mathrm{t}_{i}\right) \times 24
\end{gathered}
$$

where $\mathrm{C}_{\mathrm{R}}$ is the soil $\mathrm{CO}_{2}$ emission rate $\left(\mathrm{mg} \mathrm{C} \mathrm{kg}{ }^{-1}\right.$ dry soil h$\left.{ }^{-1}\right) ; \Delta \mathrm{C}$ is the change in $\mathrm{CO}_{2}$ concentrations (ppmv) between incubation times of $0-4 \mathrm{~h}$; $\mathrm{V}$ is the headspace volume $(\mathrm{mL})$ of the flask; $\mathrm{M}$ is the dry weight of the soil $(\mathrm{g}) ; \Delta \mathrm{t}$ is the incubation time $(\mathrm{h})$; $\mathrm{T}$ is the incubation temperature $\left({ }^{\circ} \mathrm{C}\right) ; \mathrm{C}_{\min }$ is the cumulative $\mathrm{CO}_{2}-\mathrm{C}$ emission $\left(\mathrm{mg} \mathrm{C} \mathrm{kg}{ }^{-1}\right.$ dry soil); and $\mathrm{C}_{\mathrm{R}(i)}$ and $\mathrm{C}_{\mathrm{R}(i+1)}$ are the $\mathrm{CO}_{2}$ emission rates at the time $\mathrm{t}_{i}$ and $\mathrm{t}_{i+1}$, respectively.

The SOC mineralization rates $\left(\mathrm{mg} \mathrm{kg}^{-1} \mathrm{day}^{-1}\right)$ were calculated as the average daily $\mathrm{CO}_{2}$ released during the 33-day incubation period.

\subsection{Statistical Analyses}

The data are presented as mean \pm standard error $(\mathrm{SE})(\mathrm{n}=3)$. After evaluating and ensuring that the distribution is normal and variance is homogeneous, paired $t$-tests were conducted to evaluate the treatment (land-use type and sampling time) on soil properties such as soil BD, $\mathrm{pH}$, moisture content, SOC concentration, TN concentration, C/N, SOC storage, labile SOC concentration, enzyme activity, functional gene copy number, and SOC mineralization rate. The statistical analyses were conducted with SPSS 18.0 software (SPSS Inc., Chicago, IL, USA). All graphs were drawn using the "ggplot2" package in R software. Differences were considered significant at $p<0.05$ in all analyses.

A structural equation model (SEM) was constructed using the "piecewiseSEM" package of $\mathrm{R}$ software to test hypothetical relationships. In our SEM, we only selected soil properties that were significantly affected by the forest conversion, including $\mathrm{pH}, \mathrm{MBC}$ concentration, $c b h \mathrm{I}$ gene abundance, cellobiohydrolase activity, phenol oxidase activity, and SOC mineralization rate. The SEM is based on the assumption that forest conversion affects soil $\mathrm{pH}, \mathrm{MBC}$ concentration, and $c b h \mathrm{I}$ gene abundance, which in turn affect C-degrading enzyme activities and the SOC mineralization rate. Additionally, the fitness of the SEM was checked by the Fisher's C test and Akaike information criterion (AIC), and the path was revised according to the above criteria to achieve the best fit.

\section{Results}

\subsection{Soil Physicochemical Properties and Labile SOC Fractions}

Soils from the EBF and MBP were acidic, with soil $\mathrm{pH}$ ranging from 4.12 to 4.75 . Regardless of the sampling time, the soil $\mathrm{pH}$ was always higher in MBP than in EBF (Table 1). Conversion of EBF to MBP did not significantly affect soil BD, texture, moisture content, SOC concentration and storage, $\mathrm{TN}$ concentration, $\mathrm{C} / \mathrm{N}$ ratio (Table 1 ), DOC, or ROC (Figure 1a,b). Soil MBC concentration was significantly higher in MBP than in EBF at each sampling time (Figure 1c). 
Table 1. Effects of conversion of evergreen broadleaf forests (EBF) to extensively managed Moso bamboo plantations (MBP) on selected soil properties $(n=3)$.

\begin{tabular}{|c|c|c|c|c|}
\hline Soil Property & Sampling Time & EBF & MBP & $p$-Value (Paired $t$-Tests) \\
\hline Bulk density $\left(\mathrm{g} \mathrm{cm}^{-3}\right)$ & July & $1.52 \pm 0.06$ & $1.23 \pm 0.11$ & 0.227 \\
\hline Clay (\%) & July & $32.46 \pm 1.30$ & $31.89 \pm 0.17$ & 0.668 \\
\hline \multirow{3}{*}{ Silt (\%) } & & $44.44 \pm 0.43$ & $45.06 \pm 2.09$ & 0.783 \\
\hline & & $23.10 \pm 1.44$ & $23.05 \pm 1.92$ & 0.988 \\
\hline & July & $22.45 \pm 2.67$ & $24.18 \pm 4.34$ & 0.604 \\
\hline \multirow{2}{*}{ Moisture content $(\%)$} & October & $12.59 \pm 0.83$ & $14.57 \pm 0.20$ & 0.183 \\
\hline & Mean & $17.52 \pm 2.54$ & $19.37 \pm 2.90$ & 0.225 \\
\hline \multirow{4}{*}{$\mathrm{pH}\left(\mathrm{H}_{2} \mathrm{O}\right)$} & July & $4.33 \pm 0.03$ & $4.64 \pm 0.07$ & 0.023 \\
\hline & October & $4.17 \pm 0.04$ & $4.55 \pm 0.03$ & 0.003 \\
\hline & Mean & $4.25 \pm 0.04$ & $4.60 \pm 0.04$ & $<0.001$ \\
\hline & July & $21.12 \pm 1.39$ & $23.61 \pm 2.01$ & 0.209 \\
\hline \multirow[t]{3}{*}{ Soil organic carbon (SOC) $\left(\mathrm{mg} \mathrm{kg}^{-1}\right)$} & October & $20.64 \pm 7.01$ & $22.84 \pm 4.76$ & 0.445 \\
\hline & Mean & $20.88 \pm 3.20$ & $23.22 \pm 2.32$ & 0.110 \\
\hline & July & $1.04 \pm 0.04$ & $1.67 \pm 0.26$ & 0.151 \\
\hline \multirow[t]{2}{*}{ Total nitrogen $\left(\mathrm{mg} \mathrm{kg}^{-1}\right)$} & October & $1.69 \pm 0.13$ & $1.93 \pm 0.32$ & 0.603 \\
\hline & Mean & $1.37 \pm 0.16$ & $1.80 \pm 0.19$ & 0.119 \\
\hline \multirow{4}{*}{$\mathrm{C} / \mathrm{N}$} & July & $20.45 \pm 2.14$ & $14.74 \pm 2.13$ & 0.135 \\
\hline & October & $12.93 \pm 5.30$ & $11.86 \pm 1.34$ & 0.838 \\
\hline & Mean & $16.69 \pm 3.06$ & $13.30 \pm 1.30$ & 0.240 \\
\hline & July & $64.31 \pm 6.27$ & $58.27 \pm 8.34$ & 0.634 \\
\hline \multirow[t]{2}{*}{ SOC storage $\left(\mathrm{Mg} \mathrm{ha}^{-1}\right)$} & October & $64.38 \pm 4.62$ & $54.00 \pm 5.66$ & 0.639 \\
\hline & Mean & $64.34 \pm 3.59$ & $56.13 \pm 4.61$ & 0.442 \\
\hline
\end{tabular}
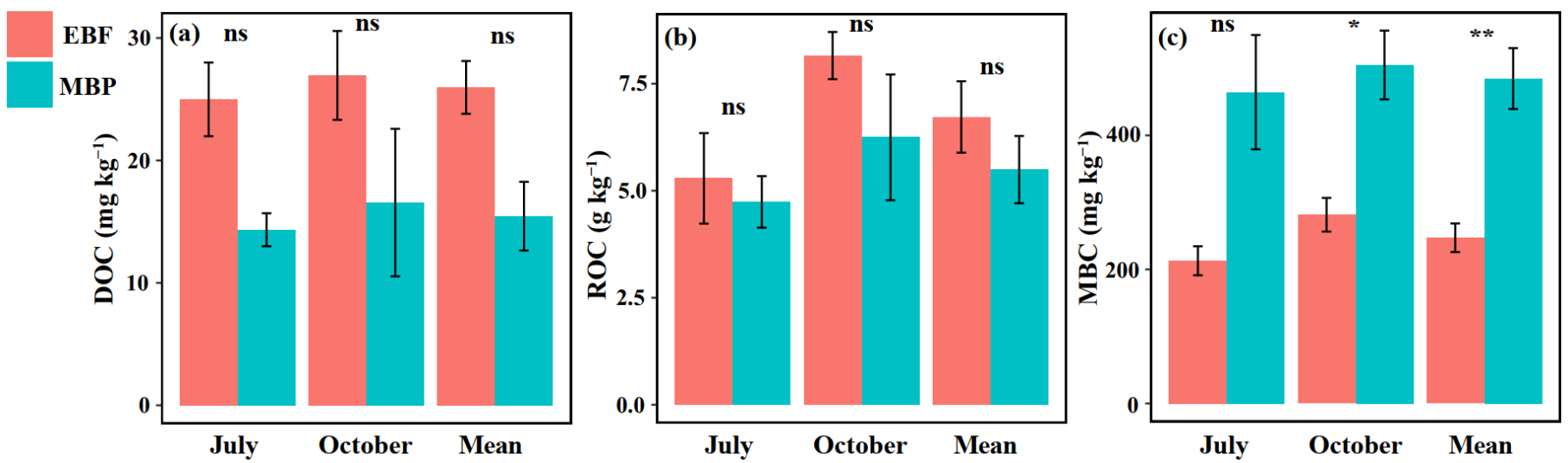

Figure 1. Effect of conversion of evergreen broadleaf forests (EBF) to extensively managed Moso bamboo plantations (MBP) on the concentration of (a) DOC, (b) ROC, and (c) MBC. * and ** indicate significant differences at the level of at $p<0.05$ and $p<0.01$, respectively $(\mathrm{n}=3)$. The error bars in the graphs represent standard errors of the mean (SE).

\subsection{SOC Mineralization Rate, Soil Enzyme Activities and Functional Genes Abundance}

The SOC mineralization was very rapid at the beginning of the incubation but declined gradually with time for the two land-use types (Figure 2a,b), and the conversion of EBF to MBP all significantly increased SOC mineralization rate (Figure 2c). The overall mean SOC mineralization rate of the two sampling times in the MBP was 1.49 times higher than that in the EBF $(p<0.01$, Figure 2c). 

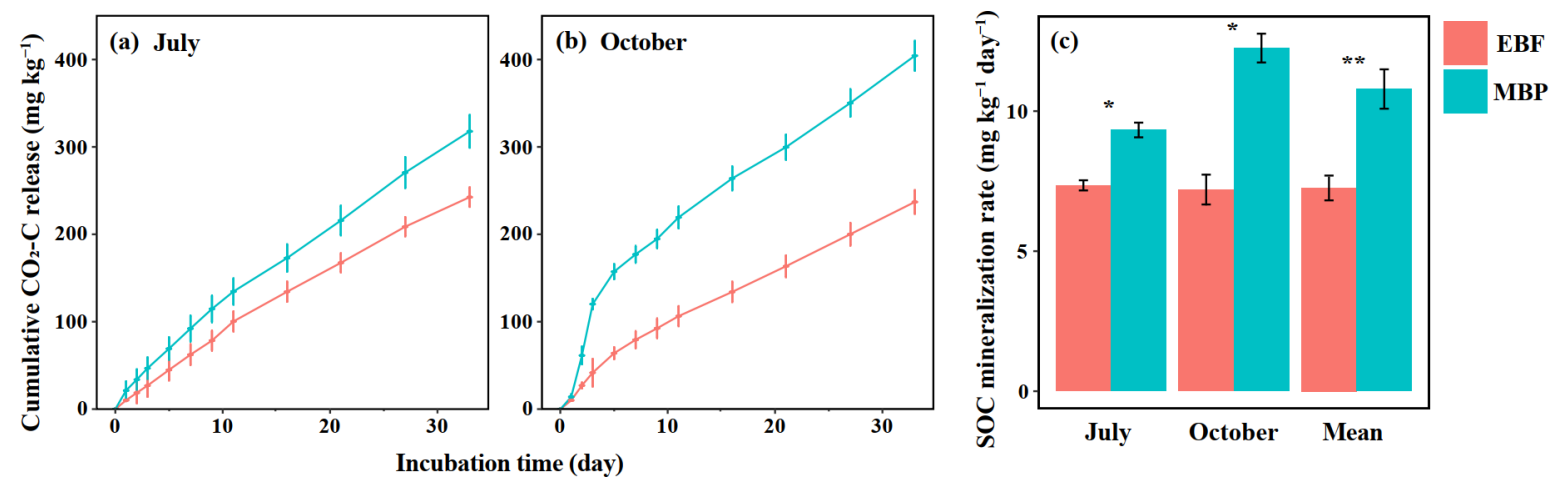

Figure 2. Effect of conversion of evergreen broadleaf forests (EBF) to extensively managed Moso bamboo plantations (MBP) on the cumulative $\mathrm{CO}_{2}-\mathrm{C}$ release in (a) July and (b) October, and (c) the SOC mineralization rate. * and ** indicate significant differences at the level of $p<0.05$ and $p<0.01$, respectively $(n=3)$. The error bars in the graphs represent standard errors of the mean $(\mathrm{SE})$.

Regardless of sampling time, soil cellobiohydrolase and phenol oxidase activities and $c b h \mathrm{I}$ gene abundance were all significantly higher in MBP than in EBF (Figure 3a,c). Soil lcc gene abundance was significantly higher in MBP than in EBF only in October (Figure 3d).
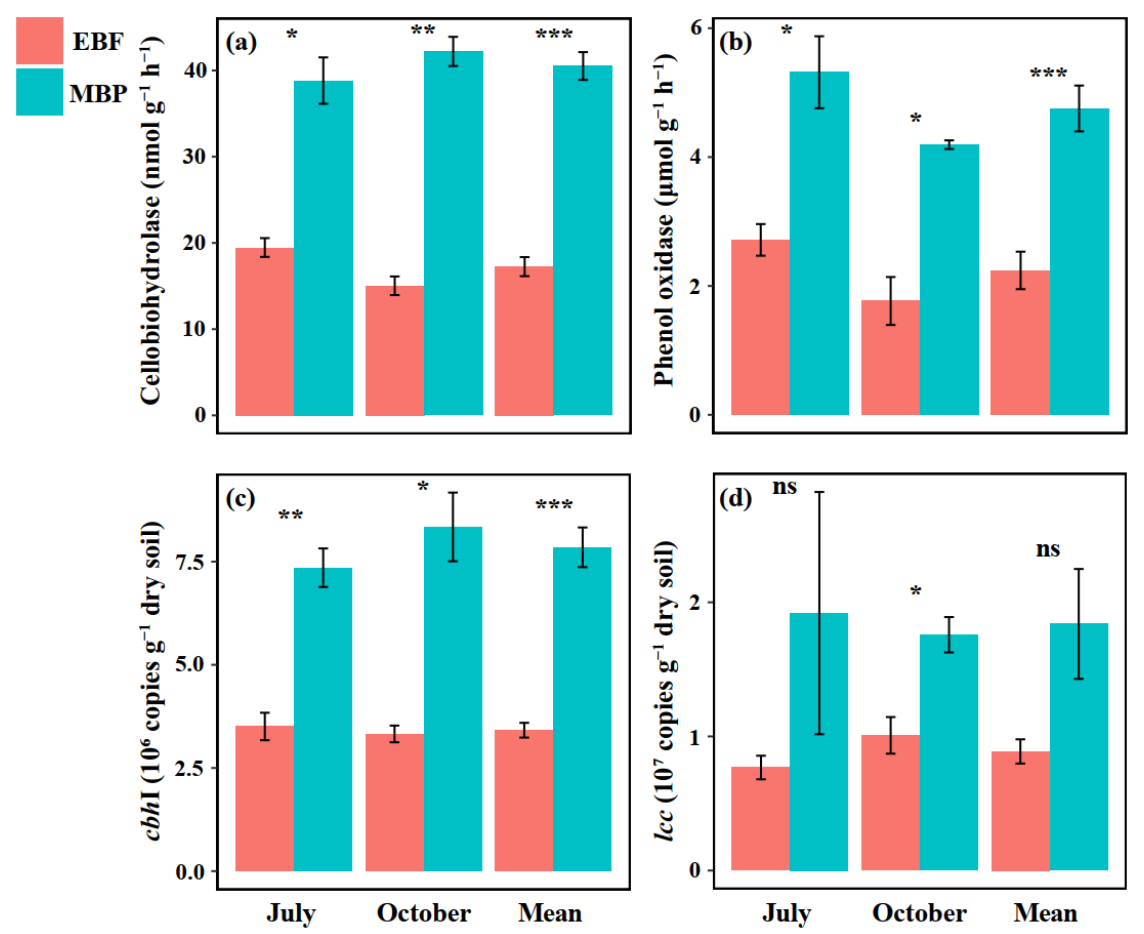

Figure 3. Effect of conversion of evergreen broadleaf forests (EBF) to extensively managed Moso bamboo plantations (MBP) on (a) cellobiohydrolase activity, (b) phenol oxidase activity, (c) cbhI gene abundance, and (d) $l c c$ gene abundance. ${ }^{*}, * *$, and ${ }^{* * *}$ indicate significant differences at the level of at $p<0.05, p<0.01$, and $p<0.001$, respectively $(\mathrm{n}=3)$. The error bars in the graphs represent standard errors of the mean (SE).

\subsection{Relationship between SOC Mineralization Rate and Soil Properties}

Forest conversion directly increased soil pH $(p<0.001)$, MBC concentration $(p<0.001)$, and $c b h$ I abundance $(p<0.001)$ (Figure 4$)$. Furthermore, a large proportion of the variation of soil cellobiohydrolase activity was described by soil $c b h \mathrm{I}(p<0.001)$ and $\mathrm{pH}(p=0.037)$, and the phenol oxidase activity variation was mainly explained by soil MBC $(p<0.001)$ (Figure 4$)$. In addition, most of the variation (74\%) in the SOC mineralization rate was explained by soil cellobiohydrolase activity $(p<0.001)$ (Figure 4$)$. The SEM showed that 
forest conversion increased soil $\mathrm{pH}$ and the abundance of $c b h \mathrm{I}$ gene, and the latter indirectly increased SOC mineralization rate through increasing the activity of cellobiohydrolase (Figure 4).

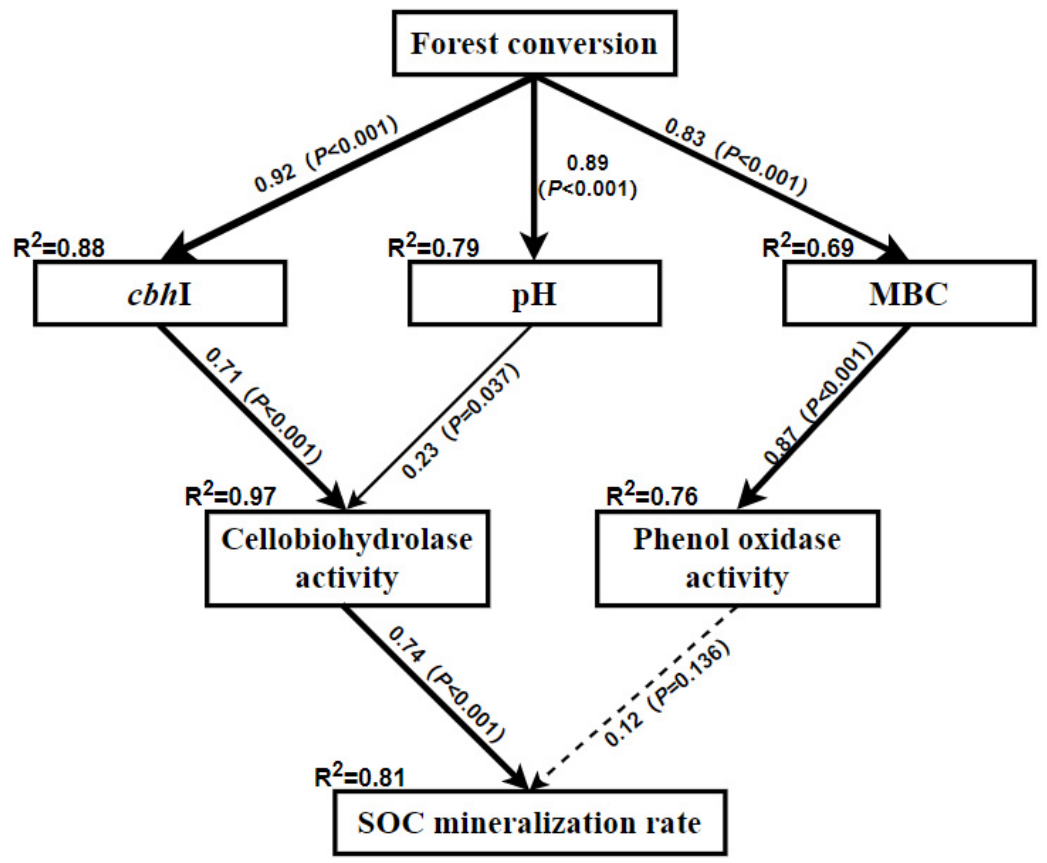

Figure 4. Structural equation modeling (SEM) of the effects of conversion of native broadleaf forests (EBF) to extensively managed Moso bamboo plantations (MBP) on SOC mineralization rates. Results of model fitting: $p=0.094 ; \mathrm{df}=26$; $\mathrm{AIC}=89.85$; Fisher's $\mathrm{C}=49.85$. The $\mathrm{R}^{2}$ values related with response variables mean the proportion of variation explained by relationships with other variables. The values related with arrows are standardized path coefficients. The solid arrows indicate significant effects $(p<0.05)$ and dotted arrows indicate no significant effects $(p>0.05)$.

\section{Discussion}

Although many studies have reported the effect of forest conversion on SOC mineralization, they mainly focused on the conversion of natural forests into intensively managed agricultural lands $[9,13]$. How the conversion of natural forest into extensively managed bamboo plantations affects SOC mineralization is still poorly understood. Interestingly, we found that converting EBF into extensively managed MBP significantly increased SOC mineralization rate (Figure 1) but did not influence SOC storage (Table 1 ) and the concentration of labile SOC fractions, i.e., DOC and ROC (Figure 2) in the surface layer $(0-20 \mathrm{~cm})$. In spite of this, converting EBF to extensively managed MBP still increased the risk of C loss via enhanced SOC mineralization.

The increase in the cumulative SOC mineralization in our finding was consistent with Wang et al. [52], who found that the cumulative soil $\mathrm{CO}_{2}-\mathrm{C}$ emissions were significantly higher in the Cunninghamia lanceolata Hook and Michelia macclurei Dandy plantations than in the natural forest long after forest conversion. The significant correlation between labile SOC fractions and cumulative SOC mineralization was also in agreement with several previous studies $[13,39,52]$. Interestingly, our results showed that converting EBF to MBP only increased the concentration of MBC but did not change the other labile SOC fractions, i.e., DOC and ROC (Figure 2). In addition, our SEM also showed that there was no significant direct relationship between MBC and SOC mineralization (Figure 4). Therefore, we can exclude the possibility that forest conversion increased the SOC mineralization rate via changing soil labile SOC concentrations in the current study. Another possible reason for the enhanced SOC mineralization is the increased activities of C-degrading enzymes $[30,32,53]$. In the present study, converting EBF to MBP significantly increased the activities of cellobiohydrolase and phenol oxidase (Figure 3), which is likely to enhance 
cellulose and lignin degradation and SOC mineralization in the MBP soil. Short-term incubation experiments also demonstrated that the change in SOC mineralization rate after forest conversion was significantly affected by the activities of C-degrading enzymes such as cellobiohydrolase, $\beta$-glucosidase, and cellulase [13,52]. Our SEM analysis also showed that increasing the activities of C-degrading enzymes after forest conversion increased the SOC mineralization rate. However, it is worth noting that in the SEM the increased phenol oxidase activity following the forest conversion did not influence $(p=0.136)$ SOC mineralization rate (Figure 4), which could be due to the fact that phenol oxidase is only responsible for degrading recalcitrant organic compounds (e.g., lignin) into smaller ones during the SOC mineralization, whereas the key step of simple organic compound degradation is mainly accomplished by hydrolytic enzymes such as cellobiohydrolase [31,34,54]. Briefly, the increased cellobiohydrolase activity after forest conversion played a greater role than phenol oxidase in the mineralization of SOC. The cellobiohydrolase activity might be influenced by the increased soil $\mathrm{pH}$ and $c b h \mathrm{I}$ gene abundance after forest conversion in the present study. Soil pH can change the enzyme activity via impacting the stability of soil enzymes [55]. Zhang et al. [33] also found that the soil C-degrading enzyme activities were driven by soil $\mathrm{pH}$ after land-use change in a subtropical ecosystem. In this study, the increase of soil pH might not be caused by the changes in the nature of soil parent materials, because the land-use change did not significantly change the soil basic properties, such as bulk density, texture, or carbon and nitrogen concentration (Table 1). Many studies found that the fluctuations in soil $\mathrm{pH}$ could be attributed to the input of plant materials [56-58]. Therefore, the increase in soil pH was probably due to the changes in the organic matter input following the land-use change in the present study. Furthermore, Nannipieri et al. [34,59] indicated that the enzyme-encoding genes are related to enzyme activity. Many previous studies have related soil enzyme activities with their respective enzyme-encoding genes [60-62]. The significant relationship of cellobiohydrolase activity to soil $\mathrm{pH}(p=0.037)$ and the abundance of $c b h$ I gene $(p<0.001)$ (Figure 4$)$ also supported these relationships. The increase in SOC mineralization after forest conversion can be regulated by increased cellobiohydrolase activities [31,32,34].

Many studies have demonstrated that converting natural forests to intensively managed plantations decrease SOC storage $[13,63,64]$. However, forest conversion in our study did not significantly change SOC storage in the surface layer, which may be related to the nature of the extensive management in MBP. The litter from above- and below-ground are important sources of SOC accumulation [65], and the quality and quantity of forest litter input are responsible for the SOC concentration and storage $[52,66]$. In the current study, the vegetation was gradually restored and the understory vegetation was also retained following the long-term extensive management after forest conversion to MBP, which subsequently maintained the abundant plant $C$ input to the soil, resulting in the lack of significant changes in the SOC concentration. Furthermore, lack of ploughing in MBP did not affect soil BD between EBF and MBP. The lack of forest conversion effect on SOC concentration and BD resulted in the lack of change in SOC storage. In spite of this, if the higher SOC mineralization rate after forest conversion is not abated, it could decrease the SOC storage in MBP if the input of litter decreases.

\section{Conclusions}

Our study provides new insights into the effect of converting natural forests to extensively managed Moso bamboo plantations on SOC mineralization rate, which was linked to activities of C-degrading enzymes. The forest conversion increased activities of cellobiohydrolase and phenol oxidase in the extensively managed Moso bamboo plantation, which could be explained by a higher soil $\mathrm{pH}, c b h \mathrm{I}$ gene abundance, and MBC concentration. The increased activities of C-degrading enzymes, especially that of cellobiohydrolase, significantly increased the SOC mineralization rate. The lack of change in SOC storage following the forest conversion suggests that the rate of organic $\mathrm{C}$ input in the extensively managed bamboo forest was greater than the rate of SOC mineralization. The enhanced 
SOC mineralization after forest conversion does suggest that the risk of SOC loss and reduction in SOC storage may increase in the event that the rate of organic $C$ input in the form of above- and below-ground litterfall falls below the rate of organic $\mathrm{C}$ mineralization. Before making decisions on land-use conversion, the impact of such conversions on the $\mathrm{C}$ cycle in the ecosystem needs to be carefully studied to ensure that no negative effect on SOC sequestration is caused by the conversion, otherwise such conversions should be avoided as much as possible.

Author Contributions: Y.C. conceptualized the study. H.Z. conducted the experiment and wrote the first draft. Y.C., X.Z. and S.X.C. went through several rounds of review/editing and added content. All authors reviewed the final manuscript. All authors have read and agreed to the published version of the manuscript.

Funding: This work was supported by the National Natural Science Foundation of China (41877088, 41950410570), the Research and Development Fund of Zhejiang A\&F University (2018FR005, 2018FR006), the Open Research Fund Program of the State Key Laboratory of Subtropical Silviculture, Zhejiang A\&F University (ZY20180301, ZY20180205).

Institutional Review Board Statement: Not applicable.

Informed Consent Statement: Not applicable.

Data Availability Statement: Not applicable.

Conflicts of Interest: The authors declare no conflict of interest.

\section{References}

1. Janzen, H.H. Carbon cycling in earth systems-A soil science perspective. Agric. Ecosyst. Environ. 2004, 104, 399-417. [CrossRef]

2. Lal, R. Forest soils and carbon sequestration. For. Ecol. Manag. 2005, 220, 242-258. [CrossRef]

3. Lal, R. Accelerated Soil erosion as a source of atmospheric $\mathrm{CO}_{2}$. Soil Till. Res. 2019, 188, 35-40. [CrossRef]

4. Ziegler, S.E.; Billings, S.A.; Lane, C.S.; Li, J.; Fogel, M.L. Warming alters routing of labile and slower-turnover carbon through distinct microbial groups in boreal forest organic soils. Soil Biol. Biochem. 2013, 60, 23-32. [CrossRef]

5. Ghazoul, J.; Burivalova, Z.; Garcia-Ulloa, J.; King, L.A. Conceptualizing Forest Degradation. Trends Ecol. Evol. $2015,30,622-632$. [CrossRef]

6. FAO. Global Forest Resources Assessment 2015: How Are the World's Forests Changing? Food and Agriculture Organization of the United Nations: Rome, Italy, 2015; pp. 1-56.

7. Gibbs, H.; Ruesch, A.; Achard, F.; Clayton, M.; Holmgren, P.; Ramankutty, N.; Foley, J. Tropical forests were the primary sources of new agricultural land in the 1980s and 1990s. Proc. Natl. Acad. Sci. USA 2010,107, 16732-16737. [CrossRef]

8. Smith, P. Land use change and soil organic carbon dynamics. Nutr. Cycl. Agroecosys. 2008, 81, 169-178. [CrossRef]

9. Fan, L.; Han, W. Soil respiration after forest conversion to tea gardens: A chronosequence study. Catena 2020, 190, 104532. [CrossRef]

10. Lyu, M.; Noormets, A.; Ukonmaanaho, L.; Li, Y.; Yang, Y.; Xie, J. Stability of soil organic carbon during forest conversion is more sensitive in deep soil than in topsoil in subtropical forests. Pedobiologia 2021, 84, 150706. [CrossRef]

11. Olson, K.R.; Gennadiyev, A.N.; Zhidkin, A.P.; Markelov, M.V. Impacts of Land-Use Change, Slope, and Erosion on Soil Organic Carbon Retention and Storage. Soil Sci. 2012, 177, 269-278. [CrossRef]

12. Shi, B.; Gao, W.; Jin, G. Effects on rhizospheric and heterotrophic respiration of conversion from primary forest to secondary forest and plantations in northeast China. Eur. J. Soil Biol. 2015, 66, 11-18. [CrossRef]

13. Lin, Z.; Li, Y.; Tang, C.; Luo, Y.; Fu, W.; Cai, X.; Li, Y.; Yue, T.; Jiang, P.; Hu, S.; et al. Converting natural evergreen broadleaf forests to intensively managed moso bamboo plantations affects the pool size and stability of soil organic carbon and enzyme activities. Biol. Fertil. Soils 2018, 54, 467-480. [CrossRef]

14. Han, M.; Zhu, B. Changes in soil greenhouse gas fluxes by land use change from primary forest. Glob. Chang. Biol. 2020, 26, 2656-2667. [CrossRef] [PubMed]

15. Wang, J.; Zou, Y.; Di Gioia, D.; Singh, B.K.; Li, Q. Conversion to agroforestry and monoculture plantation is detrimental to the soil carbon and nitrogen cycles and microbial communities of a rainforest. Soil Biol. Biochem. 2020, 147, 107849. [CrossRef]

16. Guillaume, T.; Damris, M.; Kuzyakov, Y. Losses of soil carbon by converting tropical forest to plantations: Erosion and decomposition estimated by $\delta^{13} \mathrm{C}$. Glob. Chang. Biol. 2015, 21, 3548-3560. [CrossRef] [PubMed]

17. Gupta, S.; Singh, J. Effect of alkali concentration, volume and absorption area on the measurement of soil respiration in a tropical sward. Pedobiologia 1977, 8, 233-239.

18. Schütt, M.; Borken, W.; Spott, O.; Stange, C.F.; Matzner, E. Temperature sensitivity of C and N mineralization in temperate forest soils at low temperatures. Soil Biol. Biochem. 2014, 69, 320-327. [CrossRef] 
19. Ding, X.; Qiao, Y.; Filley, T.; Wang, H.; Lü, X.; Zhang, B.; Wang, J. Long-term changes in land use impact the accumulation of microbial residues in the particle-size fractions of a Mollisol. Biol. Fertil. Soils 2017, 53, 281-286. [CrossRef]

20. Ci, E.; Al-Kaisi, M.M.; Wang, L.; Ding, C.; Xie, D. Soil Organic Carbon Mineralization as Affected by Cyclical Temperature Fluctuations in a Karst Region of Southwestern China. Pedosphere 2015, 25, 512-523. [CrossRef]

21. Kéraval, B.; Fontaine, S.; Lallement, A.; Revaillot, S.; Billard, H.; Alvarez, G.; Maestre, F.; Amblard, C.; Lehours, A.-C. Cellular and non-cellular mineralization of organic carbon in soils with contrasted physicochemical properties. Soil Biol. Biochem. 2018, 125, 286-289. [CrossRef]

22. Küstermann, B.; Munch, J.C.; Hülsbergen, K.J. Effects of soil tillage and fertilization on resource efficiency and greenhouse gas emissions in a long-term field experiment in Southern Germany. Eur. J. Agron. 2013, 49, 61-73. [CrossRef]

23. Six, J.; Conant, R.T.; Paul, E.A.; Paustian, K. Stabilization mechanisms of soil organic matter: Implications for C-saturation of soils. Plant. Soil 2002, 241, 155-176. [CrossRef]

24. Fang, X.; Zhang, J.; Meng, M.; Guo, X.; Wu, Y.; Liu, X.; Zhao, K.; Ding, L.; Shao, Y.; Fu, W. Forest-type shift and subsequent intensive management affected soil organic carbon and microbial community in southeastern China. Eur. J. For. Res. 2017, 136, 689-697. [CrossRef]

25. Ramírez, P.B.; Fuentes-Alburquenque, S.; Díez, B.; Vargas, I.; Bonilla, C.A. Soil microbial community responses to labile organic carbon fractions in relation to soil type and land use along a climate gradient. Soil Biol. Biochem. 2020, 141, 107692. [CrossRef]

26. Wallenstein, M.D.; Weintraub, M.N. Emerging tools for measuring and modeling the in situ activity of soil extracellular enzymes. Soil Biol. Biochem. 2008, 40, 2098-2106. [CrossRef]

27. Sinsabaugh, R.L.; Gallo, M.E.; Lauber, C.; Waldrop, M.P.; Zak, D.R. Extracellular Enzyme Activities and Soil Organic Matter Dynamics for Northern Hardwood Forests receiving Simulated Nitrogen Deposition. Biogeochemistry 2005, 75, 201-215. [CrossRef]

28. Edwards, I.P.; Upchurch, R.A.; Zak, D.R. Isolation of fungal cellobiohydrolase I genes from sporocarps and forest soils by PCR. Appl. Environ. Microbiol. 2008, 74, 3481-3489. [CrossRef]

29. Janssens, I.A.; Dieleman, W.; Luyssaert, S.; Subke, J.A.; Reichstein, M.; Ceulemans, R.; Ciais, P.; Dolman, A.J.; Grace, J.; Matteucci, G.; et al. Reduction of forest soil respiration in response to nitrogen deposition. Nat. Geosci. 2010, 3, 315-322. [CrossRef]

30. Chen, J.; Luo, Y.; García-Palacios, P.; Cao, J.; Dacal, M.; Zhou, X.; Li, J.; Xia, J.; Niu, S.; Yang, H.; et al. Differential responses of carbon-degrading enzyme activities to warming: Implications for soil respiration. Glob. Change Biol. 2018, 24, 4816-4826. [CrossRef]

31. Sinsabaugh, R.L. Phenol oxidase, peroxidase and organic matter dynamics of soil. Soil Biol. Biochem. 2010, 42, 391-404. [CrossRef]

32. Burns, R.G.; DeForest, J.L.; Marxsen, J.; Sinsabaugh, R.L.; Stromberger, M.E.; Wallenstein, M.D.; Weintraub, M.N.; Zoppini, A. Soil enzymes in a changing environment: Current knowledge and future directions. Soil Biol. Biochem. 2013, 58, 216-234. [CrossRef]

33. Zhang, Q.; Feng, J.; Wu, J.; Zhang, D.; Chen, Q.; Li, Q.; Long, C.; Feyissa, A.; Cheng, X. Variations in carbon-decomposition enzyme activities respond differently to land use change in central China. Land Degrad. Dev. 2019, 30, 459-469. [CrossRef]

34. Nannipieri, P.; Trasar-Cepeda, C.; Dick, R.P. Soil enzyme activity: A brief history and biochemistry as a basis for appropriate interpretations and meta-analysis. Biol. Fertil. Soils 2018, 54, 11-19. [CrossRef]

35. Chen, J.; Sinsabaugh, R.L. Linking microbial functional gene abundance and soil extracellular enzyme activity: Implications for soil carbon dynamics. Glob. Change Biol. 2021, 27, 1322-1325. [CrossRef] [PubMed]

36. Li, Y.; Li, Y.; Chang, S.X.; Yang, Y.; Fu, S.; Jiang, P.; Luo, Y.; Yang, M.; Chen, Z.; Hu, S.; et al. Biochar reduces soil heterotrophic respiration in a subtropical plantation through increasing soil organic carbon recalcitrancy and decreasing carbon-degrading microbial activity. Soil Biol. Biochem. 2018, 122, 173-185. [CrossRef]

37. Li, Y.; Zhang, J.; Chang, S.X.; Jiang, P.; Zhou, G.; Fu, S.; Yan, E.; Wu, J.; Lin, L. Long-term intensive management effects on soil organic carbon pools and chemical composition in Moso bamboo (Phyllostachys pubescens) forests in subtropical China. For. Ecol. Manag. 2013, 303, 121-130. [CrossRef]

38. Yan, W.; Mahmood, Q.; Peng, D.; Fu, W.; Chen, T.; Wang, Y.; Li, S.; Chen, J.; Liu, D. The spatial distribution pattern of heavy metals and risk assessment of moso bamboo forest soil around lead-zinc mine in Southeastern China. Soil Till. Res. 2015, 153, 120-130. [CrossRef]

39. Liu, J.; Jiang, P.; Wang, H.; Zhou, G.; Wu, J.; Yang, F.; Qian, X. Seasonal soil $\mathrm{CO}_{2}$ efflux dynamics after land use change from a natural forest to Moso bamboo plantations in subtropical China. For. Ecol. Manag. 2011, 262, 1131-1137. [CrossRef]

40. Wang, H.; Jin, J.; Yu, P.; Fu, W.; Morrison, L.; Lin, H.; Meng, M.; Zhou, X.; Lv, Y.; Wu, J. Converting evergreen broad-leaved forests into tea and Moso bamboo plantations affects labile carbon pools and the chemical composition of soil organic carbon. Sci. Total Environ. 2020, 711, 135225. [CrossRef]

41. Yang, C.; Wang, A.; Zhu, Z.; Lin, S.; Bi, Y.; Du, X. Impact of extensive management system on soil properties and carbon sequestration under an age chronosequence of Moso bamboo plantations in subtropical China. For. Ecol. Manag. 2021, $497,119535$. [CrossRef]

42. World Reference Base for Soil Resources 2014, Update 2015. In International Soil Classification System for Naming Soils and Creating Legends for Soil Maps; World Soil Resources Technical Reports No. 106; FAO: Rome, Italy, 2015.

43. Nelson, D.W.; Sommers, L.E. Total carbon, organic carbon, and organic matter. In Methods of Soil Analysis, Part 3-Chemical Methods; American Society of Agronomy: Madison, WI, USA, 1996; pp. 961-1010.

44. Bremner, J.M. Determination of nitrogen in soil by the Kjeldahl method. J. Agric. Sci. 1960, 55, 11-33. [CrossRef] 
45. Brookes, P.C.; Landman, A.; Pruden, G.; Jenkinson, D.S. Chloroform fumigation and the release of soil nitrogen: A rapid direct extraction method to measure microbial biomass nitrogen in soil. Soil Biol. Biochem. 1985, 17, 837-842. [CrossRef]

46. Vance, E.D.; Brookes, P.C.; Jenkinson, D.S. An extraction method for measuring soil microbial biomass C. Soil Biol. Biochem. 1987, 19, 703-707. [CrossRef]

47. Joergensen, R.G.; Mueller, T. The fumigation-extraction method to estimate soil microbial biomass: Calibration of the kEN value. Soil Biol. Biochem. 1996, 28, 33-37. [CrossRef]

48. Wang, H.; Liu, S.R.; Mo, J.M.; Wang, J.X.; Makeschin, F.; Wolff, M. Soil organic carbon stock and chemical composition in four plantations of indigenous tree species in subtropical China. Ecol. Res. 2010, 25, 1071-1079. [CrossRef]

49. German, D.P.; Weintraub, M.N.; Grandy, A.S.; Lauber, C.L.; Rinkes, Z.L.; Allison, S.D. Optimization of hydrolytic and oxidative enzyme methods for ecosystem studies. Soil Biol. Biochem. 2011, 43, 1387-1397. [CrossRef]

50. Zheng, T.; Liang, C.; Xie, H.; Zhao, J.; Yan, E.; Zhou, X.; Bao, X. Rhizosphere effects on soil microbial community structure and enzyme activity in a successional subtropical forest. FEMS Microbiol. Ecol. 2019, 95, fiz043. [CrossRef]

51. Luis, P.; Walther, G.; Kellner, H.; Martin, F.; Buscot, F. Diversity of laccase genes from basidiomycetes in a forest soil. Soil Biol. Biochem. 2004, 36, 1025-1036. [CrossRef]

52. Wang, Q.; Xiao, F.; He, T.; Wang, S. Responses of labile soil organic carbon and enzyme activity in mineral soils to forest conversion in the subtropics. Ann. Forest Sci. 2013, 70, 579-587. [CrossRef]

53. Allison, S.D.; Wallenstein, M.D.; Bradford, M.A. Soil-carbon response to warming dependent on microbial physiology. Nat. Geosci. 2010, 3, 336-340. [CrossRef]

54. Zhang, B.; Cai, Y.; Hu, S.; Chang, S.X. Plant mixture effects on carbon-degrading enzymes promote soil organic carbon accumulation. Soil Biol. Biochem. 2021, 163, 108457. [CrossRef]

55. Frankenberger, W.T.; Johanson, J.B. Effect of pH on enzyme stability in soils. Soil Biol. Biochem. 1982, 14, 433-437. [CrossRef]

56. Pocknee, S.; Sumner, M.E. Cation and nitrogen contents of organic matter determine its soil liming potential. Soil Sci. Soc. Am. J. 1997, 61, 86-92. [CrossRef]

57. Yan, F.; Schubert, S. Soil pH changes after application of plant shoot materials of faba bean and wheat. Plant Soil 2000, 220, 279-287. [CrossRef]

58. Yan, F.; Schubert, S.; Mengel, K. Soil pH increase due to biological decarboxylation of organic anions. Soil Biol. Biochem. 1996, 28, 17-24. [CrossRef]

59. Nannipieri, P.; Giagnoni, L.; Renella, G.; Puglisi, E.; Ceccanti, B.; Masciandaro, G.; Fornasier, F.; Moscatelli, M.C.; Marinari, S. Soil enzymology: Classical and molecular approaches. Biol. Fertil. Soils 2012, 48, 743-762. [CrossRef]

60. Pathan, S.I.; Ceccherini, M.T.; Hansen, M.A.; Giagnoni, L.; Ascher, J.; Arenella, M.; Sørensen, S.J.; Pietramellara, G.; Nannipieri, P.; Renella, G. Maize lines with different nitrogen use efficiency select bacterial communities with different $\beta$-glucosidase-encoding genes and glucosidase activity in the rhizosphere. Biol. Fertil. Soils 2015, 51, 995-1004. [CrossRef]

61. Baraniya, D.; Puglisi, E.; Ceccherini, M.T.; Pietramellara, G.; Giagnoni, L.; Arenella, M.; Nannipieri, P.; Renella, G. Protease encoding microbial communities and protease activity of the rhizosphere and bulk soils of two maize lines with different $\mathrm{N}$ uptake efficiency. Soil Biol. Biochem. 2016, 96, 176-179. [CrossRef]

62. Cañizares, R.; Moreno, B.; Benitez, E. Biochemical characterization with detection and expression of bacterial $\beta$-glucosidase encoding genes of a Mediterranean soil under different long-term management practices. Biol. Fertil. Soils 2012, 48, 651-663. [CrossRef]

63. Li, Y.; Zhang, J.; Chang, S.X.; Jiang, P.; Zhou, G.; Shen, Z.; Wu, J.; Lin, L.; Wang, Z.; Shen, M. Converting native shrub forests to Chinese chestnut plantations and subsequent intensive management affected soil C and N pools. For. Ecol. Manag. 2014, 312, 161-169. [CrossRef]

64. Chen, G.; Yang, Y.S.; Xie, J.; Guo, J.; Gao, R.; Qian, W. Conversion of a natural broad-leafed evergreen forest into pure plantation forests in a subtropical area: Effects on carbon storage. Ann. Forest Sci. 2005, 62, 659-668. [CrossRef]

65. Lal, R.; Kimble, J.M.; Follett, R.F.; Stewart, B.A. Soil Processes and the Carbon Cycle; CRC Press: Boca Raton, FL, USA, 1997; Volume 11

66. Vesterdal, L.; Schmidt, I.K.; Callesen, I.; Nilsson, L.O.; Gundersen, P. Carbon and nitrogen in forest floor and mineral soil under six common European tree species. For. Ecol. Manag. 2008, 255, 35-48. [CrossRef] 